\title{
Investigation of the Composition, Structure and Properties of New Porous Powder Friction Coatings Obtained by Plasma Sputtering
}

\author{
V. I. Karlov ${ }^{1, *}$ and Yu. I. Krykhtin ${ }^{1}$ \\ ${ }^{1}$ Volgograd State Technical University, Russia, 400005, Volgograd, Lenin Prospect, 28.
}

\begin{abstract}
The paper investigates processes of composition selection, structure formation and properties of new porous powder friction materials based on molybdenum $(\mathrm{Mo})$, on aluminum-iron bronze $($ БрАЖ $(\mathrm{SiC}))$ or steel (40X13) obtained by plasma spraying. The study can be used in the frictional devices of transmissions of tracked vehicles with a high specific power to increase the tribotechnical, operational and technological characteristics.
\end{abstract}

\section{Introduction}

In transport engineering, the issues of creating friction materials for small-sized highperformance friction devices operating in an oil environment and produced using mobile high-performance technology are relevant. An increase in the coefficient of friction $f$ when operating in oil in such friction devices is of significant importance $[1,2]$. The task is to obtain $f \geq 0.16$ instead of $f_{\max }=0.12$ for known friction materials (MK-5). The friction coefficient $f$ is included in the formula with the design parameters of the friction unit: where $M$ is the free torque of the internal combustion engine (ICE) according to the external characteristic; $i$ is the gear ratio from the crankshaft of the ICE to the shaft of the installation of the friction device; $P$ is the force of pressure on the elements of the friction pair by the control system; $R$ is the average radius of the friction surfaces; $z$ is the number of pairs of friction surfaces; $\beta$ is the friction moment margin factor of friction device.

The characteristics of the friction surfaces (physical and mechanical properties, geometric indicators, etc.) depend on the rubbing materials, the environment, external friction parameters (load, sliding speed, temperature, etc.). With an increase in the coefficient $f$ (while maintaining the friction moment $M_{f}=f \cdot P \cdot R \cdot z \cdot \beta$ ) in the design of the friction device, the design parameters of the friction unit may decrease.

It is known from the theory of elasticity that a concentrated normal force $F_{n}$ acting on an elastic half-space at the origin of coordinates causes a normal displacement $U_{z}=F_{n}\left(1-v^{2}\right) /(\pi \cdot E \cdot r)$ - the friction device is on, where E is Young's modulus; $v$ is Poisson's ratio; $r$ is the radius of curvature for the half-space.

\footnotetext{
*Corresponding author: au@vstu.ru
} 
During deformation and compaction processes in a compliant elastic porous friction coating of a part when operating in oil, a transition to the semi-dry boundary friction mode with a significant increase in the friction coefficient $f$ is possible due to the transition process between friction with lubrication and semi-dry (boundary) friction, i.e., the transition from an elastic friction coating to a rigid compressed friction covering. The minimum porosity of the coating, which is $10 \%$, is specified due to the condition of ensuring the deformation of the porous body and the accumulation of oil in the pores. The maximum porosity limit, which is $25 \%$, is specified from the condition of ensuring the strength properties of the coating since a further increase in porosity leads to a significant decrease in the strength of the coating.

The study is aimed at investigating the compositions and properties of new porous friction materials of high-performance friction products for operation in oil, manufactured with the use of mobile high-performance technology.

The study is novel in that it investigates the compositions, structure and properties of new porous powder friction plasma products with increased coefficients of friction and wear resistance when working on a steel counterbody in oil.

\section{Composition of coating materials, their structure and research methods}

Various compositions, structures and properties of new plasma powder friction coatings for operation in oil with steel counterbodies have been investigated $[3,4,5]$.

It is possible to use a gas-thermal molybdenum coating. Molybdenum is a silvery-gray refractory metal with the following properties: the density is $10.2 \mathrm{~g} / \mathrm{cm} 3$; the melting point is $t_{m e l}=2620^{\circ} \mathrm{C}$; chemically resistant; oxidizes in air at a temperature $400^{\circ} \mathrm{C}$. It is widely used in the production of alloy steels to increase their strength and hardness.

Micrographs of plasma molybdenum coatings are shown in Fig. 1. The Vickers hardness of the molybdenum coating is $4800 \ldots 5200 \mathrm{MPa}$, the porosity is $18 \ldots 21 \%$. The micrographs show the ends (transverse sections) of molybdenum plasma coatings. As can be seen from the figure, molybdenum coatings have a layered structure. The layers consist of particles of smooth elongated shape; particles are not everywhere closely adjacent to each other. At the junction of the layers and individual particles, there are cracks and microcavities in the layers. There are round pores. In the internal structure of plasma coatings made of $M o$ at high magnification (x600), a fine-grained structure of particles constituting the coating layers is clearly observed; the coating has a high porosity.

The microstructure in the transition zone between steel and a molybdenum coating obtained by the plasma method exhibits a layer thickness of the order of $1 \ldots 2$ microns. It contains a small amount of intermetallic compounds Fe3Mo2 and Fe7Mo6; there are also areas of local fusion and areas of local quenching in an extremely thin surface of the base metal layer. In particular, a thin surface layer of the pearlite structure in the areas of tight adhesion to the particles of the sprayed layer was heated during spraying to a temperature above the point of structural transformation onset, and upon subsequent rapid cooling a quasi-martensite structure appeared in these areas. The microhardness in the areas of ferite, pearlite and quasi-martensite was 950, 2300, and $5500 \mathrm{~N} / \mathrm{mm} 2$ respectively. To obtain a plasma molybdenum coating, a $1.2 \mathrm{~mm}$ molybdenum wire containing $99.9 \% \mathrm{Mo} ; 0.001 \%$ $\mathrm{Ni}, 0.001 \% \mathrm{SiO} 2$ and $0.008 \%$ sesquioxides was used in the development.

This study makes an attempt to create an effective porous gas-thermal friction coating on a bronze basis. 


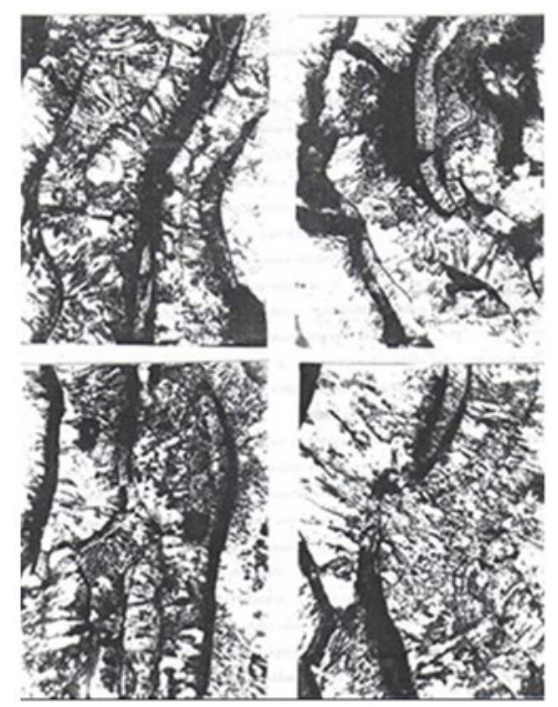

Fig. 1. Plasma molybdenum coating: x600 substrate steel St.3

After machining with abrasive blasting, a friction coating is applied either directly to the part or to the intermediate (so-called 'primer') layer of nickel aluminide ( $\mathrm{Al}-15 \%, \mathrm{Ni}-85 \%)$. The intermediate layer is applied with a thickness of $80 \ldots 120$ microns. Nickel aluminide coating can be successfully used at high temperatures - up to $650^{\circ} \mathrm{C}$, demonstrating high strength and adhesion ability. The main layer of aluminum-iron bronze is applied with a thickness of $0.2 \ldots 0.45 \mathrm{~mm}$ on the surface of the base of the friction discs or the conical blocking ring of the gearbox synchronizer.

The composition of the material $(\mathrm{Cu}+10 \% \mathrm{Al}+5 \% \mathrm{Fe}+10 \% \mathrm{SiC})$ has been determined by material science research and tribotechnical tests and corresponds to an effective combination of a carrier matrix on a copper base, which has the necessary properties of strength, wear resistance, elasticity and friction, with an abrasive filler $\mathrm{SiC}$, which is introduced to achieve the required values of the friction coefficient, as well as to stabilize the minimum friction losses under conditions of heavy loading, limited lubricant supply and high temperatures $[6,7]$.

The required structure of the plasma friction layer made of aluminum-iron bronze, in which the idea of high operational efficiency is realized in the separation of the functional purpose of the elastoplastic (single-phase structure of a solid solution of aluminum in copper $\mathrm{Al} \leq 9.4 \%$ ) and strengthening (due to the secondary phase $\mathrm{Al}_{4} \mathrm{Si}, \mathrm{Fe}_{3} \mathrm{AlCx}, \mathrm{CuAl} 2$ ) components - the base of the material is responsible for the bearing capacity, and the reinforcing component is responsible for the implementation of frictional efficiency.

Fig. 2 shows the microstructure of the bronze coating БрАЖ $(\mathrm{SiC})$. The hardness of the bronze coating according to Vickers is $1200 \ldots 1500 \mathrm{MPa}$, the porosity is $15 \ldots 20 \%$. An Xray structural study has established that the introduction of $10 \%$ aluminum into the copper base leads to the partial formation of a two-phase structure: $\alpha$ is a solid solution with inclusions of a eutectic containing a $\gamma$-phase. The solubility of iron in copper does not exceed $0.4 \ldots 0.5 \%$; therefore, almost all the amount of iron remains in the form of insoluble inclusions. 


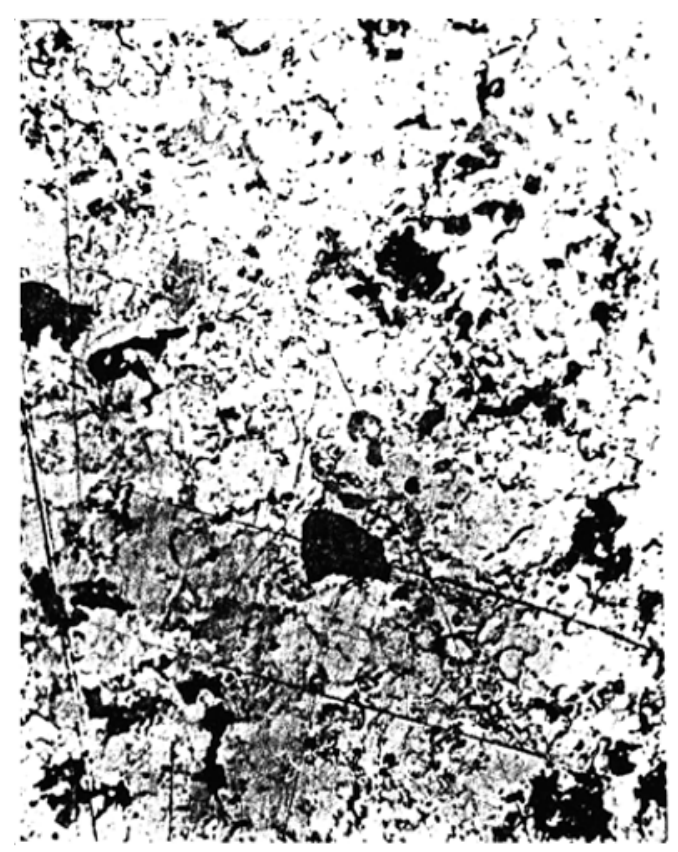

Fig. 2. The microstructure of the БрАЖ $(\mathrm{SiC})$ bronze coating (magnification $\mathrm{x} 400)$. Substrate steel St. 3

The bronze material is characterized by increased frictional activity. The approbation of materials manufactured by plasma spraying with the mechanical activation of the surface, which makes it possible to reduce the porosity to $7 \%$, revealed the possibility of rational use of aluminum-iron bronze БpAЖ $(\mathrm{SiC})$ in friction devices.

A study of the structure of plasma coatings obtained by spraying alloy steels was carried out $[6,7]$. The microstructure of plasma coatings made of 11 Х $18 \mathrm{MBД} \mathrm{steel} \mathrm{is} \mathrm{shown} \mathrm{in}$ Fig. 3.

The figure shows that the steel coatings have a layered structure. The layers are mainly composed of particles in the form of thin curved sheets. However, in steel plasma coatings, there are quite a large number of spherical particles and particles of irregular round shape. At x600 magnification, the internal structure of the coating layers is better revealed. It can be seen that spherical particles are located not only along the boundaries of the layers, but also inside the layers themselves. The steel coating has a fairly high porosity. Considering the steel coatings at low / x115 / magnifications, we see that the steel coatings have a thin structure. In steel coatings, small layer widths and particle sizes in the layers are observed. The hardness of the coating based on steel 40X13 according to Rockwell is not less than HRC 40; porosity is $18 \ldots 20 \%$.

The adhesion strength of all considered coatings must be at least $22 \mathrm{MPa}$.

This study also deals with investigating the formation process and determining the properties of steel plasma coatings in order to improve the service characteristics of cone inertial synchronizers of the gearbox. 


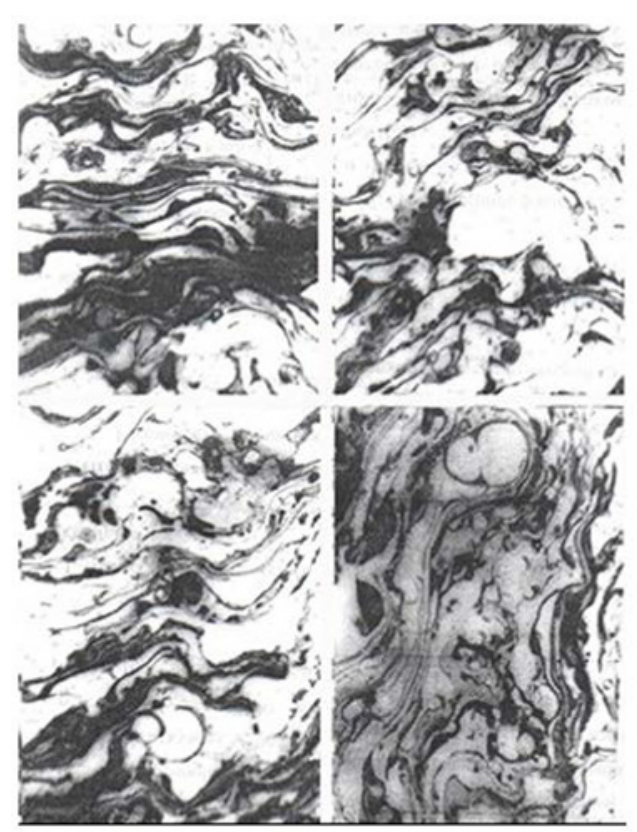

Fig. 3. Plasma coating based on steel 11Х18МВД: $\mathrm{x} 600$, substrate steel St. 3

The development of compositions and technology for coating cone synchronizers promises great prospects in creating compact friction pairs with low material consumption, which is extremely necessary for modern machines in terms of reducing their weight and ensuring the high reliability of friction units [8].

\section{Research and discussion results}

The variations of the ultimate setting loads, wear resistance and the coefficient of friction of a powder friction material (PFM) based on 40X13 steel with respect to its porosity were revealed (Fig.4) - MT-66 friction machine at a sliding speed of $6 \mathrm{~m} / \mathrm{s}$, with a specific pressure of 3.5 MPa under conditions of limited lubricant supply. The friction material is a porous heterogeneous structure consisting of particles of troostite, martensite and hardened sorbitol.

The results of tribotechnical tests on the MT-68 friction machine of new porous powder friction materialsm obtained by the method of plasma spraying and operating in oil, are presented in Table. 1

Comparing the behavior of the material made of bronze and molybdenum, it can be noted that at the same rate of wear, the material made of bronze is characterized by increased frictional efficiency. The approbation of materials manufactured by plasma spraying with mechanical activation of the surface, making it possible to reduce the porosity to $7 \%$, demonstrates the possibility of rational use of aluminum-iron bronze БрАЖ $(\mathrm{SiC})$ in synchronizing devices. 

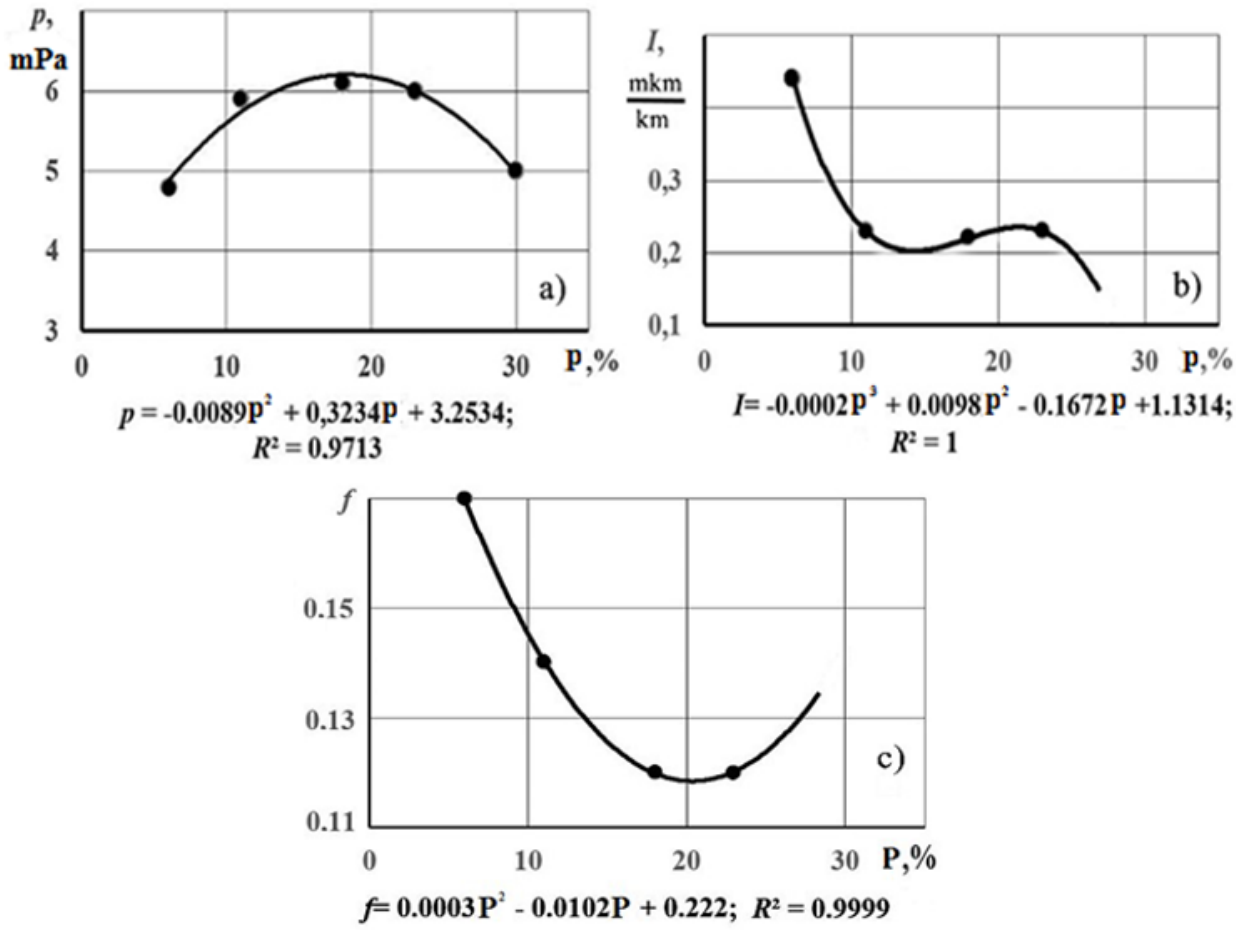

Fig. 4. Graphs of the variations of the studied parameters of friction PFM based on steel 40X13 with a counterbody made of steel $\left.\left.20 \mathrm{X} 2 \mathrm{H} 4 \mathrm{~A}, \mathrm{HRC}=58: \mathrm{a})-p=F_{1}(\mathrm{P}) ; \mathrm{b}\right)-I=F_{2}(\mathrm{P}) ; \mathrm{c}\right)-f=F_{3}(\mathrm{P})$, where $p$ is the specific setting pressure; $I$ is the rate of wear; $f$ is the coefficient of friction; $\mathrm{P}$ is the porosity index; $R^{2}$ is the accuracy of approximation

Table 1. The results of tribotechnical tests on the MT-68 friction machine

\begin{tabular}{|c|c|c|c|c|c|c|}
\hline $\begin{array}{l}\text { Friction } \\
\text { pair }\end{array}$ & Indicators & $\begin{array}{l}V=5 \mathrm{~m} / \mathrm{s} ; \\
P=60 \mathrm{kG} / \mathrm{cm} 2\end{array}$ & $\begin{array}{l}V=10 \mathrm{~m} / \mathrm{s} ; \\
P=40 \mathrm{kG} / \mathrm{cm} 2\end{array}$ & $\begin{array}{l}V=20 \mathrm{~m} / \mathrm{s} ; \\
P=20 \mathrm{kG} / \mathrm{cm} 2\end{array}$ & $\begin{array}{l}V=25 \mathrm{~m} / \mathrm{s} ; \\
P=10 \mathrm{kG} / \mathrm{cm} 2\end{array}$ & $\begin{array}{l}V=30 \mathrm{~m} / \mathrm{s} ; \\
P=5 \mathrm{kG} / \mathrm{cm} 2\end{array}$ \\
\hline \multirow{3}{*}{ 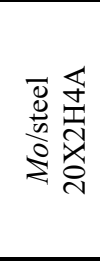 } & $\begin{array}{l}\text { Wear rate, }[\mu \mathrm{m} \\
\mathrm{km}]\end{array}$ & 10 & 8 & $<5$ & 10 & $<5$ \\
\hline & \begin{tabular}{|l}
$\begin{array}{l}\text { Friction } \\
\text { coefficient }\end{array}$ \\
\end{tabular} & 0.05 & 0.11 & 0.19 & 0.35 & 0.70 \\
\hline & $\begin{array}{l}\text { Temperature in } \\
\text { the contact zone, } \\
{\left[{ }^{\circ} \mathrm{C}\right]}\end{array}$ & 60 & 94 & 148 & 162 & 184 \\
\hline \multirow{3}{*}{ 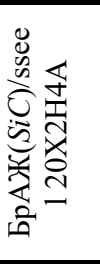 } & $\begin{array}{l}\text { Wear rate, }[\mu \mathrm{m} \\
\mathrm{km}]\end{array}$ & 15 & $<5$ & $<5$ & 25 & 20 \\
\hline & $\begin{array}{l}\text { Friction } \\
\text { coefficient }\end{array}$ & 0.05 & 0.15 & 0.22 & 0.35 & 0.50 \\
\hline & $\begin{array}{l}\text { Temperature in } \\
\text { the contact zone, } \\
{\left[{ }^{\circ} \mathrm{C}\right]}\end{array}$ & 75 & 90 & 105 & 125 & 138 \\
\hline \multirow{3}{*}{ 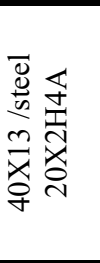 } & $\begin{array}{l}\text { Wear rate, }[\mu \mathrm{m} \\
\mathrm{km}]\end{array}$ & $<5$ & $<5$ & $<5$ & $<5$ & 10 \\
\hline & $\begin{array}{l}\text { Friction } \\
\text { coefficient }\end{array}$ & 0.10 & 0.12 & 0.20 & 0.32 & 0.40 \\
\hline & $\begin{array}{l}\text { Temperature in } \\
\text { the contact zone, } \\
{\left[{ }^{\circ} \mathrm{C}\right]}\end{array}$ & 76 & 90 & 125 & 144 & 154 \\
\hline
\end{tabular}




\begin{tabular}{|c|c|c|c|c|c|c|}
\hline $\begin{array}{l}\text { Friction } \\
\text { pair }\end{array}$ & Indicators & $\begin{array}{l}V=5 \mathrm{~m} / \mathrm{s} ; \\
P=60 \mathrm{kG} / \mathrm{cm} 2\end{array}$ & $\begin{array}{l}V=10 \mathrm{~m} / \mathrm{s} ; \\
P=40 \mathrm{kG} / \mathrm{cm} 2\end{array}$ & $\begin{array}{l}V=20 \mathrm{~m} / \mathrm{s} \\
P=20 \mathrm{kG} / \mathrm{cm} 2\end{array}$ & $\begin{array}{l}V=25 \mathrm{~m} / \mathrm{s} ; \\
P=10 \mathrm{kG} / \mathrm{cm} 2\end{array}$ & $\begin{array}{l}V=30 \mathrm{~m} / \mathrm{s} \\
P=5 \mathrm{kG} / \mathrm{cm} 2\end{array}$ \\
\hline \multirow{3}{*}{ 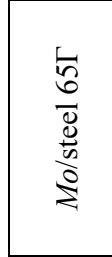 } & $\begin{array}{l}\text { Wear rate, }[\mu \mathrm{m} \\
\mathrm{km}]\end{array}$ & $<5$ & $<5$ & $<5$ & $<5$ & $<5$ \\
\hline & $\begin{array}{l}\text { Friction } \\
\text { coefficient }\end{array}$ & 0.08 & 0.10 & 0.19 & 0.45 & 0.60 \\
\hline & $\begin{array}{l}\text { Temperature in } \\
\text { the contact zone, } \\
{\left[{ }^{\circ} \mathrm{C}\right]}\end{array}$ & 71 & 92 & 150 & 165 & 180 \\
\hline \multirow{3}{*}{ 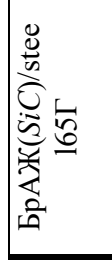 } & $\begin{array}{l}\text { Wear rate, }[\mu \mathrm{m} \\
\mathrm{km}]\end{array}$ & 50 & 35 & 20 & 10 & $<5$ \\
\hline & \begin{tabular}{|l}
$\begin{array}{l}\text { Friction } \\
\text { coefficient }\end{array}$ \\
\end{tabular} & 0.12 & 0.16 & 0.30 & 0.40 & 0.20 \\
\hline & $\begin{array}{l}\text { Temperature in } \\
\text { the contact zone, } \\
{\left[{ }^{\circ} \mathrm{C}\right]}\end{array}$ & 80 & 135 & 142 & 140 & 155 \\
\hline \multirow{3}{*}{ 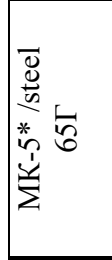 } & $\begin{array}{l}\text { Wear rate, }[\mu \mathrm{m} \\
\mathrm{km}]\end{array}$ & $<5$ & $<5$ & $<5$ & $<5$ & $<5$ \\
\hline & $\begin{array}{l}\text { Friction } \\
\text { coefficient }\end{array}$ & 0.09 & 0.12 & 0.25 & 0.50 & 0.70 \\
\hline & $\begin{array}{l}\text { Temperature in } \\
\text { the contact zone, } \\
{\left[{ }^{\circ} \mathrm{C}\right]}\end{array}$ & 72 & 100 & 170 & 181 & 190 \\
\hline
\end{tabular}

* - serial material made by separate pressing and long-term pressure sintering

Similar conclusions can be attributed to materials based on molybdenum, however, taking into account the fact that the frictional efficiency of molybdenum is characterized by a lower level. The operation of synchronizing devices that correspond to the frictional interaction of materials made of stainless steel 12XH3A steel - 20X2H4A steel can be improved by replacing one of the steels with bronze or molybdenum. This is evidenced by laboratory tests for friction and wear of samples made of aluminum-iron bronze and molybdenum.

Low values of the wear rate in the proposed materials can predetermine the increased service life of experimental materials in a real unit of the synchronizing device, and high coefficients of friction, i.e., the required level of frictional efficiency.

New technical solutions for friction products with plasma porous friction coatings for operation in oil are as follows:

1. The blocking cage of the inertial synchronizer for gearbox with a friction gasthermal coating, shown in Fig.5.

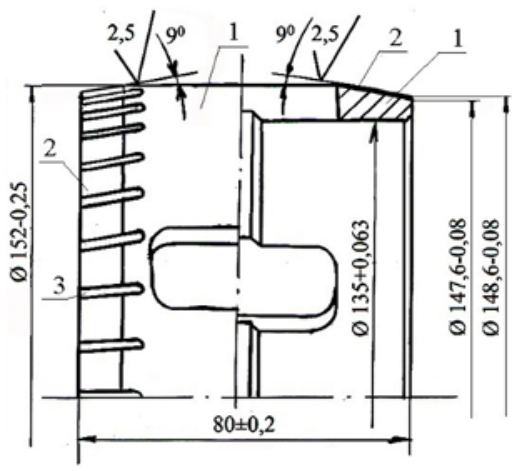

Fig. 5. Blocking cage of the inertial synchronizer with a friction gas-thermal coating: 1 - base (steel 12XH3A); 2 - coating based on steel У10A, steel 40X13, Mo, БpАЖ9-4( $\mathrm{SiC}) ; 3$ - groove. 
2. Plasma-coated friction discs shown in Fig.6.

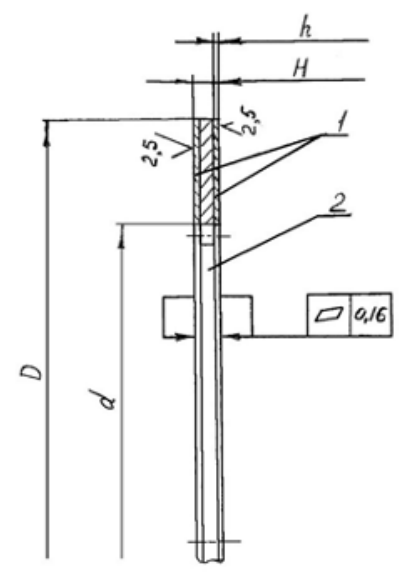

\begin{tabular}{|l|l|l|l|}
\hline $\mathrm{D}$ & $\mathrm{d}$ & $\mathrm{H}$ & $\mathrm{h}$ \\
\hline $216 \pm 1$ & $168 \pm 0.5$ & $3-0.075$ & $0.25^{+0.06}$ \\
\hline $176 \pm 0.1$ & $133^{+1}$ & $3,3-0.075$ & $0.25^{+0.06}$ \\
\hline
\end{tabular}

Fig. 6. Plasma coated friction discs: 1-friction material; 2- disk base.

An increase in the operational properties of friction devices with a porous powder plasma friction coating for operation in oil with a steel counterbody is carried out due to a rational combination of physical and mechanical properties, its manufacturing technology and loading modes [9].

\section{Summary}

The developed frictional porous plasma coatings based on molybdenum, aluminum-iron bronze or steels for working with a steel counterbody with lubrication can be used to create new friction devices for transmissions of light tracked vehicles with a high specific power operating in extreme conditions.

This study was supported by the Russian Foundation for Basic Research and the Administration of the Volgograd Region under project No. 19-48-340021.

\section{References}

1. V.A. Belyj, A.I. Sviridenok, Aktualnye napravleniya razvitiya issledovanij v oblasti tribologii, Trenie i iznos., 7:4 (1986), pp. 593- 603.

2. V.V.SHapovalov, A.Sladkovski, A.CH.Erkenov, Aktualnye zadachi sovremennoj tribotekhniki i puti ih resheniya, Izvestiya vysshihuchebnyh zavedenij. Mashinostroenie, 1:658 (2015), pp.64-75.

3. Hasui A., Morigaki O. Naplavka i napylenie M.: Mashinostroenie, (1985) p. 239.

4. Truhanov V.M., Zubkov V.F., Kryhtin YU.I., ZHeltobryuhov V.F. Transmissii gusenichnyh i kolesnyh mashin. M.: Mashinostroenie, (2001) p. 736.

5. Fedorchenko I.M., Francevich I.N., Radomyselskiy I.D. Poroshkovaya metallurgiya, materialy, tekhnologii, svojstva, oblasti primeneniya. Spravochnik. Kiev.: Naukova dumka, (1985) p. 623.

6. Trenie, iznashivanie i smazka. Spravochnik. Kniga 1, Pod red. I.V.Kragelskogo, V.V.Alisina, Moskva, Mashinostroenie, (1978). 
7. A.P.Lyubchenko, B.B.Glushkova, V.P.Tarabanova, YU.V.Ryzhkov, Vliyanie gazotermicheskogo napyleniya na strukturu i tverdost' poverhnostnogo sloya, Vestnik HNADU, 42 (2008).

8. Dvizhushchayasya sherohovataya poverhnost, Trudy amerikanskogo obshchestva inzhenerov-mekhanikov: Problemy treniya i smazki. per. s angl., M.: izd, Mir, 3 (1988), pp. 103-107.

9. I.S.Kulikov, S.V.Vashchenko, A.YA.Kamenev, Elektronno-plazmennaya obrabotka materialov, Nacional'naya akademiya nauk Belarusi; Obyedinennyy institut energeticheskih i yadernyh issledovanij «Sosny». Minsk: Belaruskaya navuka, (2010), p. 231. 